\title{
Vector competence of Culicoides biting midges from Switzerland for African horse sickness virus and epizootic haemorrhagic disease virus
}

\author{
Maurer, Lena M ; Paslaru, Anca ; Torgerson, Paul R ; Veronesi, Eva ; Mathis, Alexander
}

\begin{abstract}
Culicoides biting midges unexpectedly arose in Europe as highly efficient vectors of bluetongue virus in the epidemics that started in the Netherlands in 2006. They are known vectors of other orbiviruses, such as African horse sickness (AHSV) and epizootic haemorrhagic disease viruses (EHDV), which are not endemic to Europe. We investigated whether Culicoides occurring in Switzerland at two altitudes (Swiss Plateau, 650 meters above sea level [masl]; and pre-alpine, 2,130 masl) can act as vectors for AHSV and EHDV (two strains each). Biting midges were collected from farms, allowed to feed on virus-spiked blood meals through an artificial membrane in the laboratory and incubated for eight days under two temperature regimes $\left(22 \pm 6{ }^{\circ} \mathrm{C}\right.$ or $\left.26 \pm 6{ }^{\circ} \mathrm{C}\right)$ reflecting a summer day or a hot spell on the Swiss Plateau. Vector competence was assessed from head homogenates by RT-qPCR and virus isolation. Overall, over 15,000 biting midges were exposed to any one of the four viruses. Fully disseminated infections were identified for all four virus strains in 14 individuals $(6 \mathrm{C}$. obsoletus, 8 C. scoticus, as identified by MALDI-TOF mass spectrometry), all originating from the Swiss Plateau, by RT-qPCR. Viable virus could be isolated from 8 of these specimens. Dissemination rates ranged from 1-5\%. No viral dissemination was observed in biting midges from the high altitude, predominantly belonging to the species C. grisescens, which were only investigated at the high temperature regime. However, a multivariable logistic regression model revealed no statistical difference in the dissemination rates based on the origin of midges (altitude), virus strain or temperature regime. Thus, AHDV and EHDV transmission is feasible on the Swiss Plateau but unlikely in the pre-alpine area by considering vector abundance. Ways of potential virus introduction include illegal animal movement but also long-distance wind-dispersal of infectious Culicoides.
\end{abstract}

DOI: https://doi.org/10.17236/sat00337

Posted at the Zurich Open Repository and Archive, University of Zurich ZORA URL: https://doi.org/10.5167/uzh-214177

Journal Article

Published Version

Originally published at:

Maurer, Lena M; Paslaru, Anca; Torgerson, Paul R; Veronesi, Eva; Mathis, Alexander (2021). Vector competence of Culicoides biting midges from Switzerland for African horse sickness virus and epizootic haemorrhagic disease virus. Schweizer Archiv für Tierheilkunde, 164(1):66-70.

DOI: https://doi.org/10.17236/sat00337 


\title{
Vector competence of Culicoides biting midges from Switzerland for African horse sickness virus and epizootic haemorrhagic disease virus\#
}

\author{
L.M. Maurer ${ }^{1}$, A. Paslaru1, P.R. Torgerson², E. Veronesi ${ }^{1,+}$ A. Mathis ${ }^{1,+}$ \\ ${ }^{1}$ National Centre for Vector Entomology, Institute of Parasitology, Vetsuisse Faculty, University of Zürich, \\ Zürich, Switzerland; ${ }^{2}$ Section of Epidemiology, Vetsuisse Faculty, University of Zürich, Zürich, Switzerland
}

https://doi.org/ $10.17236 /$ sat00337

Eingereicht: 19.05.2021 Angenommen: 16.11 .2021

${ }^{+}$co-senior authors

\#Prof. Dr. med. vet Peter Deplazes zur Pensionierung gewidmet.

\section{Vektorkompetenz von Culicoides} Gnitzen aus der Schweiz für das Virus der Afrikanischen Pferdepest und das Virus der Epizootischen Hämorrhagischen Krankheit

Die Gnitzen der Gattung Culicoides traten in Europa unerwartet als hocheffiziente Überträger des Blauzungenkrankheitsvirus auf in der Epidemie, die 2006 in den Niederlanden begann. Sie sind auch Überträger anderer Orbiviren, wie z.B. der Erreger der Afrikanischen Pferdepest (AHSV) und der Epizootischen Hämorrhagischen Krankheit (EHDV), die in Europa nicht endemisch sind. Wir untersuchten, ob Culicoides, die in der Schweiz in zwei Höhenlagen vorkommen (Schweizer Mittelland, $650 \mathrm{~m}$ ü. M.; Voralpen, $2130 \mathrm{~m}$ ü.M.), als Vektoren für AHSV und EHDV (jeweils zwei Stämme) fungieren können.

Die Gnitzen wurden auf landwirtschaftlichen Betrieben gesammelt, im Labor durch eine künstliche Membran mit virusversetztem Blutmahl gefüttert und acht Tage lang bei zwei Temperaturregimes $\left(22 \pm 6^{\circ} \mathrm{C}\right.$ oder $26 \pm$ $\left.6{ }^{\circ} \mathrm{C}\right)$ inkubiert, welche einen Sommertag oder eine Hitzeperiode im Schweizer Mittelland widerspiegeln. Die Vektorkompetenz wurde durch RT-qPCR und Virusisolierung aus homogenisierten Gnitzen-Köpfen bestimmt. Insgesamt wurden über 15,000 Gnitzen einem der vier Viren ausgesetzt.

Bei 14 Individuen (6 C. obsoletus, 8 C. scoticus, identifiziert durch MALDI-TOF-Massenspektrometrie), die alle aus dem Schweizer Mittelland stammten, wurden für alle vier Virusstämme vollständig disseminierte Infektionen festgestellt durch RT-qPCR. Lebensfähige Viren konnten aus 8 dieser Insekten isoliert werden. Die Disseminationsraten reichten von 1-5\%. Bei den Gnitzen aus der höheren Lage, die überwiegend zur Art C. grisescens gehören und nur mit dem hohen Temperaturregime untersucht wurden, wurde keine Virusinfektion

\section{Summary}

Culicoides biting midges unexpectedly arose in Europe as highly efficient vectors of bluetongue virus in the epidemics that started in the Netherlands in 2006. They are known vectors of other orbiviruses, such as African horse sickness (AHSV) and epizootic haemorrhagic disease viruses (EHDV), which are not endemic to Europe. We investigated whether Culicoides occurring in Switzerland at two altitudes (Swiss Plateau, 650 meters above sea level [masl]; and pre-alpine, 2,130 masl) can act as vectors for AHSV and EHDV (two strains each).

Biting midges were collected from farms, allowed to feed on virus-spiked blood meals through an artificial membrane in the laboratory and incubated for eight days under two temperature regimes $\left(22 \pm 6^{\circ} \mathrm{C}\right.$ or $\left.26 \pm 6^{\circ} \mathrm{C}\right)$ reflecting a summer day or a hot spell on the Swiss Plateau. Vector competence was assessed from head homogenates by RT-qPCR and virus isolation. Overall, over 15,000 biting midges were exposed to any one of the four viruses.

Fully disseminated infections were identified for all four virus strains in 14 individuals (6 C.obsoletus, 8 C. scoticus, as identified by MALDI-TOF mass spectrometry), all originating from the Swiss Plateau, by RT-qPCR. Viable virus could be isolated from 8 of these specimens. Dissemination rates ranged from $1-5 \%$. No viral dissemination was observed in biting midges from the high altitude, predominantly belonging to the species $C$. grisescens, which were only investigated at the high temperature regime. However, a multivariable logistic regression model revealed no statistical difference in the dissemination rates based on the origin of midges (altitude), virus strain or temperature regime.

Thus, AHDV and EHDV transmission is feasible on the Swiss Plateau but unlikely in the pre-alpine area by considering vector abundance. Ways of potential virus in- 
festgestellt. Ein multivariables logistisches Regressionsmodell ergab jedoch keinen statistischen Unterschied in den Infektionsraten in Abhängigkeit von der Herkunft der Gnitzen (Höhe), dem Virusstamm oder dem Temperaturregime.

Somit ist eine Übertragung von AHDV und EHDV im Schweizer Mittelland möglich, im Voralpengebiet jedoch unwahrscheinlich, wenn man die Häufigkeit der Vektoren mitberücksichtigt. Mögliche Wege der Viruseinschleppung sind illegale Tierverbringungen, aber auch die Windverbreitung infektiöser Culicoides über weite Distanzen.

Schlüsselwörter: Rinder, Hirsche, Pferde, OrbivirusEinschleppung, Voralpengebiet, Schweizer Mittelland troduction include illegal animal movement but also long-distance wind-dispersal of infectious Culicoides.

Keywords: Cattle, cervids, horses, orbivirus introduction, pre-alpine area, Swiss plateau
Vector competence of Culicoides biting midges from Switzerland for African horse sickness virus and epizootic haemorrhagic disease virus

L.M. Maurer et al.

\section{Introduction}

Biting midges of the genus Culicoides (Diptera, Ceratopogonidae) are small, blood-feeding insects. They play a very important role in the development of equine insect bite hypersensitivity in Europe, against which prophylactic and therapeutic vaccines have recently been developed. ${ }^{16}$ In 2006, biting midges were identified in northern Europe as vectors of bluetongue virus (BTV) which unexpectedly spread very rapidly for the first time across most of north-western Europe, causing enormous damages to the livestock industry. ${ }^{6}$ Mass vaccination programmes eliminated the virus ${ }^{39}$ but it has re-emerged in recent years (for the updated situation in Europe, see OIE webpage). Biting midges are also vectors of other pathogens that cause diseases of veterinary importance, including African horse sickness virus (AHSV) ${ }^{9}$, epizootic haemorrhagic disease virus (EHDV) ${ }^{29}$ and Schmallenberg virus (SBV) ${ }^{37}$. AHSV and EHDV (genus Orbivirus, family Reoviridae) are closely related to BTV, with nine $(\mathrm{AHSV})^{9}$ respectively seven (EHDV) ${ }^{29}$ serotypes. The pathogenesis of both AHSV and EHDV is similar to BTV, i.e. initial virus replication in the lymph nodes draining the site of infection, then dissemination to secondary sites such as lung and spleen where replication occurs in endothelial cells and mononuclear phagocytes. ${ }^{3,19}$

Four different clinical forms of African horse sickness can be differentiated: pulmonary, cardiac, mixed and mild horse sickness fever. Clinical signs include fever, respiratory distress, dyspnoea and sudden death, with mortality rates of up to $90 \%$ in naïve horse populations. ${ }^{9}$ Most wild and domestic ruminants are susceptible hosts of EHDV. In few species, e.g. white-tailed deer (Odocoileus virginianus) in North America, the virus causes severe disease, including excessive bleeding with disseminated intravasal coagulation as well as oedema and haemorrhages in multiple organs. ${ }^{29}$ European wild cervids are less susceptible to EHDV, which rarely causes clinical disease in livestock species, apparently only in cattle. ${ }^{11}$ Along with clinical signs, abortion and infertility and a severe reduction in milk production has been observed during outbreaks of EHDV, resulting in significant economic losses. ${ }^{29}$

Endemic transmission of AHSV occurs in sub-Saharan Africa. However, since the 1950s several outbreaks have been reported. ${ }^{9}$ Between 1987 and 1991 an outbreak of AHSV-4 occurred on the Iberian Peninsula, originating from zebras imported from Namibia, causing the deaths of 3,000 equids. The virus was able to persist for three years until vaccination and slaughter policies halted the spread. 9 EHDV is endemic in regions of Africa, Asia, Australia and North America. Europe is presently free of EHDV. However, since 2006, serotypes 6 and 7 caused several outbreaks in regions close to or bordering Europe, specifically Turkey, Israel and North Africa. ${ }^{29}$

The principal vector of AHSV is Culicoides imicola, which occurs in Africa, Southeast Asia and Southern Europe along the Mediterranean basin. ${ }^{8}$ During the previous AHSV outbreak on the Iberian Peninsula, the virus was isolated from pools of insects that did not contain C. imicola, but several other Culicoides species (including C. obsoletus, C. pulicaris). ${ }^{20}$ These Culicoides species are widely distributed and abundant across central and northern Europe. Several Culicoides species have been incriminated as vectors of EHDV in endemic areas, including C. imicola. ${ }^{29}$ However, experimental work orininating form Italy suggests that field-collected $C$. obsoletus and C. scoticus are susceptible to EHDV infection. ${ }^{13}$ Thus, concerning vectors, parallels can be drawn to BTV, which is predominantly transmitted by C. imicola in Africa. This virus was efficiently transmitted by other vectors in Europe, such as the native and highly abundant Culicoides species that belong to the same sub- 
Vector competence of Culicoides biting midges from Switzerland for African horse sickness virus and epizootic haemorrhagic disease virus

L.M. Maurer et al. ef potentially competent species. ${ }^{27,40}$ In the present study, we investigated whether Culicoides, occurring in Switzerland at two different altitudes (Swiss Plateau, 650 meters above sea level [masl]; pre-alpine, 2,130 masl), can act as vectors for AHSV and EHDV. Investigations were carried out under laboratory conditions, using two temperature regimes that reflect a summer day or a hot spell on the Swiss Plateau.

\section{Material and Methods}

\section{Culicoides collection}

Culicoides were collected from a horse farm on the Swiss Plateau (650 masl; Zürich area; 47²2’31”N, 8³4'56”E; Koeppen-Geiger climate classification Cfb, www.koeppen-geiger.vu-wien.ac.at.) and from a farm in the pre-alpine region (2130 masl; Juf; 46²6 '41" N, 9³4'51"E; housing cattle, sheep and chicken; classification Dfb). Insects were caught alive in cages $(17,5 \times 17,5 \times 17,5 \mathrm{~cm}$; BugDorm 42222F; MegaView Science, Taiwan) using Onderstepoort UV light traps, as previously described. ${ }^{18}$ Traps were placed on the outside walls of barn buildings 1,5-2 $\mathrm{m}$ above ground, and an additional trap was operated inside the hen house at the pre-alpine site. Cages were transferred to incubators (Panasonic MIR-154, Japan) with fluctuating temperature regimes of either 22 $\pm 6^{\circ} \mathrm{C}$ (low fluctuating temperature regime, LFT) or 26

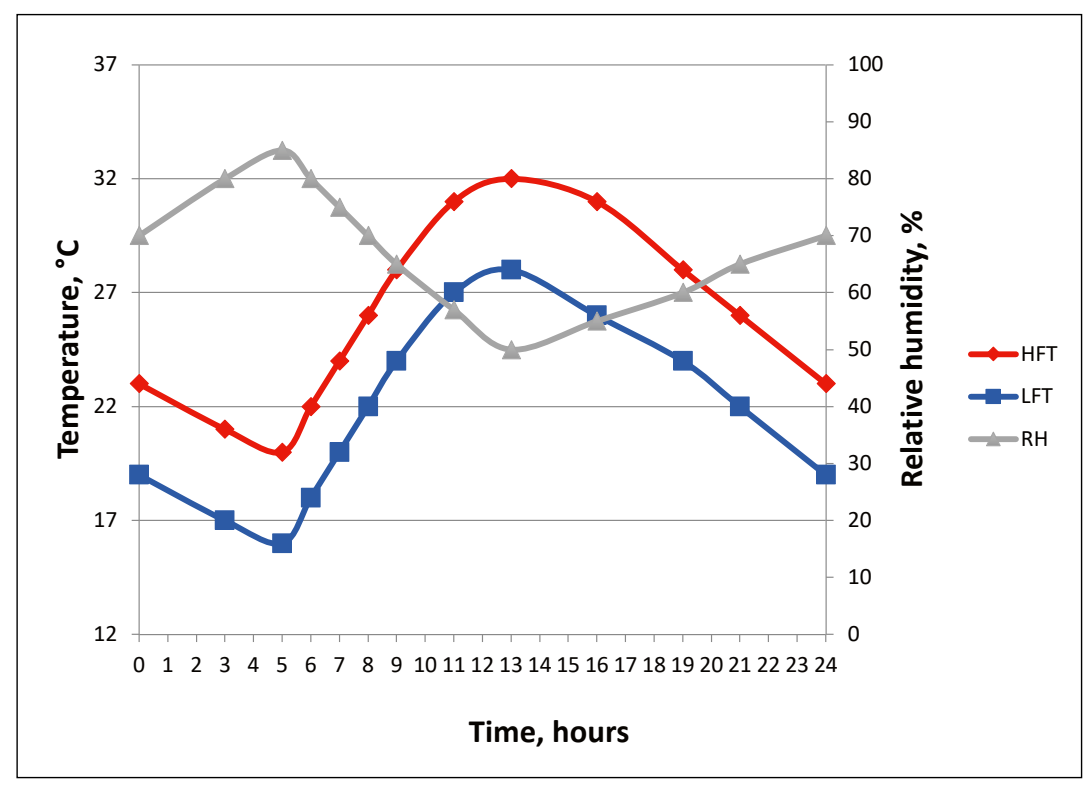

Figure 1: Fluctuating temperature regimes (high, HFT; low, LFT) and relative humidity $(\mathrm{RH})$ during incubation of virus exposed Culicoides. $\pm 6^{\circ} \mathrm{C}$ (high fluctuating temperature regime, HFT) and relative humidity $(\mathrm{RH})$ of $50-85 \%$ (Figure 1). Cotton wool pads soaked with $10 \%$ sucrose solution were supplied in the cages and renewed daily.

\section{Virus}

The virus strains were AHSV-4 (MB3 BHK3 03/11/87), AHSV-9 (MB3 BHK6 11/10/90), EHDV-6 (TUR2007/01 KC1), EHDV-7 (ISR2006/07 E1/KC2). Viruses were propagated in Vero cells as described earlier ${ }^{24}$ but in smaller cell culture flasks $\left(75 \mathrm{~cm}^{2}\right)$ and through the addition of $100 \mu \mathrm{l}$ of virus stock and $20 \mathrm{ml}$ of Glasgow Minimum Essential Media (GMEM, Gibco, Thermo Fisher Scientific, Reinach, Switzerland) with $1 \%$ antibiotics and fungizone (1000 IU/ml penicillin/streptomycin; $4 \mathrm{\mu g} / \mathrm{ml}$ amphotericin; Gibco) (GMEM complete) and $2 \%$ foetal calf serum (FCS, Bioconcept, Allschwil, Switzerland).

Viruses were quantified by titration of ten-fold serial dilutions on Vero cells in a 96-well plate, and the tissue culture infectious dose $\left(\mathrm{TCID}_{50} / \mathrm{ml}\right)$ was transformed into PFU/ml. Reverse transcription-quantitative polymerase chain reaction (RT-qPCR) was performed on the viruses, and standard curves were generated by converting cycle quantification $\left(\mathrm{C}_{\mathrm{q}}\right)$ values into $\mathrm{PFU} / \mathrm{ml}$. Standard curves showed the following $\mathrm{R}^{2}$ correlation coefficients: AHSV-4: 0,991; AHSV-9: 0,996; EHDV-6: 0,991; EHDV-7: 0,999. The final inocula of AHSV-4, AHSV-9 and EHDV-7 were obtained after two passages, the one for EHDV- 6 after three passages. The respective titres were $6,75,7,0,7,25$ and $6,25 \log _{10} \mathrm{TCID}_{50} / \mathrm{ml}$. The titres of the blood meals (see below) were 6,0 (AHSV-4, AHSV-9, EHDV-6) or 6,25 (EHDV-7) $\log _{10} \mathrm{TCID}_{50} / \mathrm{ml}$. Dilution ratios of virus supernatant and blood were 1:2 (EHDV-6), 1:5 (AHSV-4) or 1:10 (AHSV-9; EHDV-7).

\section{Vector competence}

On day four (d4) post collection, Culicoides were starved for $24 \mathrm{hrs}$, and live insects were collected at $\mathrm{d} 5 \mathrm{using}$ a mouth aspirator and placed in a paper cup covered with a net. Culicoides were anaesthetized for $1 \mathrm{~min}$ at $-20{ }^{\circ} \mathrm{C}$, then transferred to a feeding chamber covered with $\mathrm{Ne}$ scofilm50 MMx 40M (Alfresa Pharma Corporation, Japan), where they fed on virus-spiked blood for 45-60 min. ${ }^{24}$ Fully engorged females were incubated for eight days under either of the two aforementioned fluctuating temperature regimes. All Culicoides that survived the incubation period were stored individually in $1,5 \mathrm{ml}$ Eppendorf tubes at $-80^{\circ} \mathrm{C}$. One blood-fed female (d0, immediately after blood feeding) and one aliquot of the virus-spiked blood were collected for each feeding and stored at $-80^{\circ} \mathrm{C}$.

Culicoides were dissected, and the heads were manually homogenised in $100 \mathrm{\mu l} \mathrm{GMEM}$ complete with $2 \%$ FCS 
and supplemented to $1 \mathrm{ml}$ as described. ${ }^{24}$ Aliquots (140 $\mu 1)$ were processed immediately for viral RNA extraction, and the rest of the homogenates were stored at $-80^{\circ} \mathrm{C}$. All feeding, incubation, dissection and homogenisation of infected Culicoides were performed in a laboratory of biosafety level 3 (BSL3).

Virus detection, quantification and isolation Nucleic acid extractions were carried out using a QIAamp viral RNA mini kit (Qiagen, Hilden, Germany) following the manufacturer's instructions. RNA was isolated from the individual head homogenates as described 24 and amplified by RT-qPCR in a CFX96 Touch real-time system (Bio-Rad Laboratories, Cressier, Switzerland). PCRs were done in $25 \mu 1$ reaction mixes (iTaq Universal probes one-step kit, Bio-Rad Laboratories, Hercules, CA, USA) containing 0,6 $\mu 1$ of iScript advanced reverse transcriptase. Oligonucleotide sequences were kindly provided by the Institute of Virology and Immunology (Mittelhäusern, Switzerland) and were used at $20 \mu \mathrm{M}$ (primers) or $5 \mu \mathrm{M}$ (probes): AHS_VP7_4_F
Vector competence of Culicoides biting midges from Switzerland for African horse sickness virus and epizootic haemorrhagic disease virus

L.M. Maurer et al.

Table 1: Culicoides populations from different areas screened for virus presence in the head (dissemination) after exposure to blood spiked with virus (AHSV-4, AHSV-9, EHDV-6, EHDV-7) a

\begin{tabular}{|c|c|c|c|c|c|}
\hline $\begin{array}{l}\text { Origin of } \\
\text { Culicoides }\end{array}$ & Experiment ${ }^{c}$ & $\begin{array}{l}\text { No. Culicoides blood- } \\
\text { fed/survived incubation } \\
\text { period/positive for virus } \\
\text { (dissemination rate in } \% \text {; } \\
\quad 95 \% \mathrm{Cl} \text { ) }\end{array}$ & $\begin{array}{l}\text { RT-qPCR } \\
\text { positive } \\
\text { species }^{e}\end{array}$ & $\begin{array}{c}\text { Cq values }^{d} \\
\text { (virus isolation; } \\
\text { passage) }\end{array}$ & $\begin{array}{l}\text { RT-qPCR } \\
\text { negative } \\
\text { species }^{\text {e }}\end{array}$ \\
\hline \multirow{10}{*}{$\begin{array}{l}\text { Swiss Plateau } \\
(650 \text { masl)b }\end{array}$} & \multirow[b]{2}{*}{ AHSV-4 HFT } & \multirow[b]{2}{*}{$529 / 81 / 4(5 ; 1,4-12,2 \%)$} & 1 C. obsoletus & 31,6 (V3) & \multirow{2}{*}{$\begin{array}{c}40 \text { C. obsoletus } \\
9 \text { C. scoticus } \\
5 \text { C. segnis } \\
23 \text { unknown }\end{array}$} \\
\hline & & & 3 C. scoticus & $\begin{array}{l}32,6 \text { (no), } \\
33,4 \text { (no), } \\
33,8 \text { (V2) }\end{array}$ & \\
\hline & AHSV-4 LFT & $292 / 100 / 1(1 ; 0-5,5 \%)$ & 1 C. obsoletus & 32,9 (no) & $\begin{array}{c}73 \text { C. obsoletus } \\
18 \text { C. scoticus } \\
8 \text { unknown }\end{array}$ \\
\hline & AHSV-9 HFT & $520 / 105 / 1(1 ; 0-5,2 \%)$ & 1 C. obsoletus & 29,2 (V3) & $\begin{array}{c}63 \text { C. obsoletus } \\
22 \text { C. scoticus } \\
19 \text { unknown }\end{array}$ \\
\hline & AHSV-9 LFT & $276 / 111 / 0(0 ; 0-3,3 \%)$ & none & & $\begin{array}{l}48 \text { C. obsoletus } \\
24 \text { C. scoticus } \\
2 \text { C. chiopterus } \\
37 \text { unknown }\end{array}$ \\
\hline & EHDV-6 HFT & $379 / 82 / 1(1 ; 0-6,6 \%)$ & 1 C. scoticus & $29,4(V 3)$ & $\begin{array}{c}20 \text { C. obsoletus } \\
36 \text { C. scoticus } \\
25 \text { unknown }\end{array}$ \\
\hline & EHDV-6 LFT & $348 / 107 / 2(2 ; 0,2-6,6 \%)$ & 2 C. scoticus & $\begin{array}{l}29,0 \text { (V3), } \\
29,7 \text { (V3) }\end{array}$ & $\begin{array}{l}84 \text { C. obsoletus } \\
5 \text { C. scoticus } \\
1 \text { C. dewulfi } \\
1 \text { C. chiopterus } \\
14 \text { unknown }\end{array}$ \\
\hline & \multirow[t]{2}{*}{ EHDV-7 HFT } & \multirow[t]{2}{*}{$1361 / 179 / 5(3 ; 0,9-6,4 \%)$} & 3 C. obsoletus & $\begin{array}{l}32,7 \text { (V3), } \\
32,8 \text { (V3), } \\
33,0 \text { (no) }\end{array}$ & \multirow{2}{*}{$\begin{array}{c}134 \text { C. obsoletus } \\
26 \text { C. scoticus } \\
13 \text { unknown }\end{array}$} \\
\hline & & & 2 C. scoticus & $\begin{array}{l}36,2 \text { (no), } \\
36,7 \text { (no) }\end{array}$ & \\
\hline & EHDV-7 LFT & $268 / 89 / 0(0 ; 0-4,1 \%)$ & none & & $\begin{array}{l}47 \text { C. obsoletus } \\
12 \text { C. scoticus } \\
1 \text { C. lupicaris } \\
29 \text { unknown }\end{array}$ \\
\hline \multirow{2}{*}{$\begin{array}{l}\text { Pre-alpine } \\
\text { (2130 masl) }\end{array}$} & AHSV-4 HFT & $305 / 51 / 0(0 ; 0-7 \%)$ & none & & $\begin{array}{c}8 \text { C. grisescens I } \\
24 \text { C. grisescens II } \\
19 \text { unknown }\end{array}$ \\
\hline & EHDV-7 HFT & $340 / 101 / 0(0 ; 0-3,6 \%)$ & none & & $\begin{array}{c}27 \text { C. grisescens I } \\
32 \text { C. grisescens II } \\
1 \text { C. scoticus } \\
41 \text { unknown }\end{array}$ \\
\hline
\end{tabular}

aTitres (log10TCID50/ml) of the blood meals were 6,0 (AHSV-4, AHSV-9, EHDV-6) or 6,25 (EHDV-7). Ratios of virus cell culture supernatant and blood were 1:2 (EHDV-6), 1:5 (AHSV-4), 1:10 (AHSV-9, EHDV-7).

bmasl: meters above sea level

cTemperature regime: $\mathrm{HFT}$, high fluctuating temperature regime $\left(22 \pm 6^{\circ} \mathrm{C}\right)$; LFT, low fluctuating temperature regime $\left(26 \pm 6{ }^{\circ} \mathrm{C}\right)$.

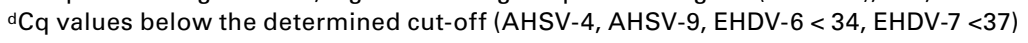

especies identified by MALDI-TOF MS analyses or by PCR/sequencing (only RT-qPCR positive specimens)

fVirus isolation on Vero cells 
Vector competence of Culicoides biting midges from Switzerland for African horse sickness virus and epizootic haemorrhagic disease virus

L.M. Maurer et al.
(5’-ATG-AAT-GGT-GTT-GTY-GCG-CC-3'), AHS_VP7_ 4_R (5'-CTA-ATG-AAA-GCG-GTG-ACC-GT-3') and probe AHS_Aguero_P (5'-FAM-GCT-AGC-AGC-CTACCA-CTA-3'-MGB) as well as EHD_NS1_F (5'-ACWGGV-ATC-ATG-TTT-GAG-CT-3'), EHD_NS1_R(5'-TTCATA-ACY-GCR-CCT-TCA-TC-3') and probe EHD_NS1_ P1 (5'-FAM-TCA-TCA-CAC-ATC-GGC-3'-BHQ1) (supplier Microsynth, Balgach, Switzerland).

The reactions were run with $5 \mu \mathrm{l}$ (AHSV) or $2 \mu \mathrm{RNA}$ solution (EHDV). As positive and negative controls, RNA extracted from AHSV/EHDV virus stocks and RNase-free $\mathrm{H}_{2} \mathrm{O}$ were used, respectively. The reactions were run with the following cycle conditions: reverse transcription $\left(10 \mathrm{~min}\right.$ at $\left.50{ }^{\circ} \mathrm{C}\right)$, reverse transcriptase inactivation and Taq polymerase activation $(3 \mathrm{~min}$ at $95^{\circ} \mathrm{C}$ ), followed by 45 (AHSV) or 50 (EHDV) cycles of $15 \mathrm{~s}$ at $95^{\circ} \mathrm{C}, 30 \mathrm{~s}$ at $57^{\circ} \mathrm{C}$ (AHSV) or $56^{\circ} \mathrm{C}$ (EHDV), $30 \mathrm{~s}$ at $72^{\circ} \mathrm{C}$.

All Culicoides heads positive for viral RNA were also tested for the presence of infectious virus particles by isolation on Vero cells using 6-well plates. Head homogenate (400 $\mu$ l) was inoculated onto each well layered with approximately $70 \%$ confluent Vero cells, followed by incubation at room temperature for $30 \mathrm{~min}$. GMEM complete with $2 \%$ FCS was added for a final volume of $4 \mathrm{ml}$ per well. After incubation for seven days at $37{ }^{\circ} \mathrm{C}$ with $5 \%$ $\mathrm{CO}_{2}$, a second blind passage was carried out by inoculating $400 \mu \mathrm{l}$ of the supernatants of passage 1 (V1) onto 6-well plates containing Vero cells and amplified as described above, generating passage 2 (V2). If no cytopathic effect (CPE) was present after V2, this step was repeated to reach passage $3(\mathrm{~V} 3)$. If no CPE was detected after three passages, no further tests were performed.

\section{Culicoides identification}

Culicoides were identified to species level using matrix-assisted laser desorption/ionisation time-of-flight mass spectrometry (MALDI-TOF MS) using homogenised thoraxes as described. ${ }^{24}$ In case mass spectrometry yielded an unidentifiable protein spectrum, PCR and sequencing were done for the individuals that had also tested positive for viral RNA in RT-qPCR as described. ${ }^{24}$

\section{Statistical analyses}

A multivariable logistic regression model was used to analyse whether temperature regime, altitude of the sampling site or virus strain the survival rate of bloodfed Culicoides, as well as on the dissemination rate of viruses. The analyses were performed using $\mathrm{R}$ (https:// www.R-project.org/).

\section{Results}

Culicoides could be caught on the Swiss Plateau between mid-June and late October 2019 and 2020, while at the pre-alpine location, Culicoides were collected between mid-July and mid-September of both years. No Culicoides were catched with the indoor trap operated at the pre-alpine site. A total of 13,337 midges from the Swiss Plateau and 1,924 midges from the pre-alpine site were exposed to infectious blood meals. The complete set of intended vector competence experiments could be done with the midges from the Swiss Plateau (all four virus strains were investigated at both temperature regimes). In contrast, the fewer Culicoides collected at the higher site were used in two experimental settings (one strain of each virus, only higher temperature regime) (Table

Table 2: Viral RNA quantified by RT-qPCR (Cq) detected in virus-spiked blood samples used for oral exposure of field-collected Culicoides and in whole engorged Culicoides immediately after feeding (day 0$\left.)^{\text {) }}\right)^{a}$

\begin{tabular}{|c|c|c|c|c|c|}
\hline $\begin{array}{l}\text { Origin of } \\
\text { Culicoides }\end{array}$ & Experiment ${ }^{b}$ & $\begin{array}{l}\text { Number of } \\
\text { feedings }\end{array}$ & $\begin{array}{l}\text { Number of Culicoides ex- } \\
\text { posed to virus/blood-fed } \\
\text { (feeding rate in } \% ; 95 \% \mathrm{CI} \text { ) }\end{array}$ & $\begin{array}{c}\text { Blood Cq } \\
\text { values (range) }\end{array}$ & $\begin{array}{l}\text { Culicoides day } 0 \mathrm{Cq} \text { values } \\
\text { range (outliers) }\end{array}$ \\
\hline \multirow{8}{*}{$\begin{array}{l}\text { Swiss Plateau } \\
\text { (650 masl)a }\end{array}$} & AHSV-4 HFT & 12 & $3229 / 529(16 ; 15-18 \%)$ & $17,9-19,5$ & $30,0-33,6(37,9,43,9)$ \\
\hline & AHSV-4 LFT & 4 & $728 / 292(40 ; 37-44 \%)$ & $17,9-21,1$ & $31,3-33,3$ \\
\hline & AHSV-9 HFT & 7 & $1330 / 520(39 ; 36-42 \%)$ & $17,6-19,8$ & $31,0-33,3$ \\
\hline & AHSV-9 LFT & 5 & $910 / 276(30 ; 27-33 \%)$ & $18,5-23,7$ & $30,0-33,6$ \\
\hline & EHDV-6 HFT & 10 & $1088 / 379(35 ; 32-38 \%)$ & $15,2-20,4$ & $27,8-32,0(35,9,36,1)$ \\
\hline & EHDV-6 LFT & 5 & $1110 / 348(31 ; 29-34 \%)$ & $15,0-17,3$ & $25,2-32,1$ \\
\hline & EHDV-7 HFT & 15 & $3627 / 1361(38 ; 36-39 \%)$ & $20,7-22,3$ & $32,3-36,7(39,6,41,7,49,5)$ \\
\hline & EHDV-7 LFT & 8 & $1315 / 268(20 ; 18-23 \%)$ & $19,9-22,7$ & $32,0-35,4(42,6)$ \\
\hline \multirow{2}{*}{$\begin{array}{l}\text { Pre-alpine } \\
\text { (2130 masl) }\end{array}$} & AHSV-4 HFT & 4 & $819 / 305(37 ; 34-41 \%)$ & $19,1-21,0$ & $28,4-31,7$ \\
\hline & EHDV-7 HFT & 10 & $1105 / 340(31 ; 28-34 \%)$ & $16,6-22,7$ & $27,0-35,2(40,2,44,9)$ \\
\hline
\end{tabular}

amasl: meters above sea level

bTemperature regimes: $\mathrm{HFT}$, high fluctuating temperature regime $\left(22 \pm 6^{\circ} \mathrm{C}\right)$; $\mathrm{LFT}$, low fluctuating temperature regime $\left(26 \pm 6^{\circ} \mathrm{C}\right)$. 
1), with a range of 4-15 feedings per experiment (Table 2). Different ratios of virus-cell culture supernatant and blood were used in order to have similar viral titres of approximately $6 \log _{10} \mathrm{TCID}_{50} / \mathrm{ml}$ in the blood inoculum. The Cq values of the blood meals used for the vector competence studies and of the engorged $\mathrm{d} 0$ midges are shown in Table 2.

Feeding rates ranged from $16-40 \%$ and survival rates from $13-44 \%$ (Table 1; Figure 2). A higher survival rate was associated with higher altitude $(\mathrm{OR}=1,82, \mathrm{p}<$ $0,001)$, lower temperature $(\mathrm{OR}=2,64, \mathrm{p}<0,001)$ and strain AHSV-9 (AHSV-9 > EHDV-7, OR $=1,45, \mathrm{p}<$ 0,01; AHSV-9 > AHSV-4, OR = 1,56, $\mathrm{p}<0,001$ ).

Overall, 34 Culicoides resulted in a positive RT-qPCR result, with $C_{q}$ values ranging from 29,0 to 48,2 . When applying a cut-off of $\mathrm{C}_{\mathrm{q}} \leq 34$ (AHSV-4, AHSV-9, EHDV6) or $\mathrm{C}_{\mathrm{q}} \leq 37$ (EHDV-7) as determined from the standard curves of the virus strains, the number of Culicoides with fully disseminated infections was 14 (6 C. obsoletus, 8 C. scoticus), all originating from the Swiss Plateau (Table 1). Positive individuals were found for each of the four virus strains at the high fluctuating temperature regime (HFT) and for AHSV-4 and EHDV-6 also at the lower temperature regime (LFT). The highest dissemination rate was $5 \%$ for AHSV-4 at HFT, and it was $1 \%$ at the LFT. AHSV-9 yielded only one positive insect at HFT. Dissemination rates of 1-2\% were determined for EHDV-6 under the two temperature regimes. Three percent of the biting midges exposed to EHDV-7 were positive for the virus at HFT but none at LFT. However, there was no statistical difference in the dissemination rates based on virus strain, origin of midges (altitude) or temperature regime.

The 14 Cq positive individuals from the Swiss Plateau were further examined by virus isolation on Vero cells. Viable virus of all four strains was demonstrated with head homogenates from 8 specimens, with CPE observed after 2 (one case) or 3 (7) viral passages (Table 1).

Species identification of all individual Culicoides that had taken a blood meal was attempted by MALDI-TOF mass spectrometry. The most abundant species by far on the Swiss Plateau were C. obsoletus and C. scoticus (Table 1), with the former being more abundant in most experiments. Other species were present only in very low numbers (C. chiopterus, C. dewulfi, C. lupicaris, $C$. segnis). At the pre-alpine site, the cryptic species $C$.grisescens I and II were dominating, with $C$. obsoletus and $C$. scoticus being virtually absent. A relatively high number of individuals (232 out of 1,006, $23 \%$ ) yielded low-quality spectra in the mass spectrometry analysis and could not be classified with this approach.

\section{Discussion}

\section{Vector competence}

In this study, the vector competence of field-collected Culicoides from both Swiss Plateau and pre-alpine areas after oral exposure to two strains of AHSV (AHSV-4, AHSV-9) and two strains of EHDV (EHDV-6, EHDV-7) under two temperature regimes was examined. Specimens with fully disseminated virus (i.e. positive heads) rather than positive salivary glands or saliva were considered potentially competent for AHSV or EHDV transmission since salivary gland barriers, in contrast to the situation in mosquitoes, have not been described for Culicoides species. ${ }^{14}$

Virus dissemination and thus vector competence was confirmed for all four virus strains in C. obsoletus and/ or C. scoticus, with overall dissemination rates between $1-5 \%$. These two Culicoides species are highly abundant at lower altitudes, with catches of up to 20,000 individuals in a single trap night, ${ }^{17}$ and thus have a considerable vector capacity for the investigated viruses. As expected, dissemination rates were higher at the higher incubation temperature as previously demonstrated with other orbiviruses.7,22,25,38 Culicoides from the pre-alpine area, predominantly $C$. grisescens as in earlier studies, ${ }^{23,24}$ could only be examined with two virus strains (AHSV4 and EHDV-7) and at one (the higher) incubation temperature, due to the limited number of insects available. Their seasonal activity is much shorter and their abundance lower ( $\max .2,000$ per single trap night $\left.{ }^{17}\right)$. Although none of the biting midges from the pre-alpine

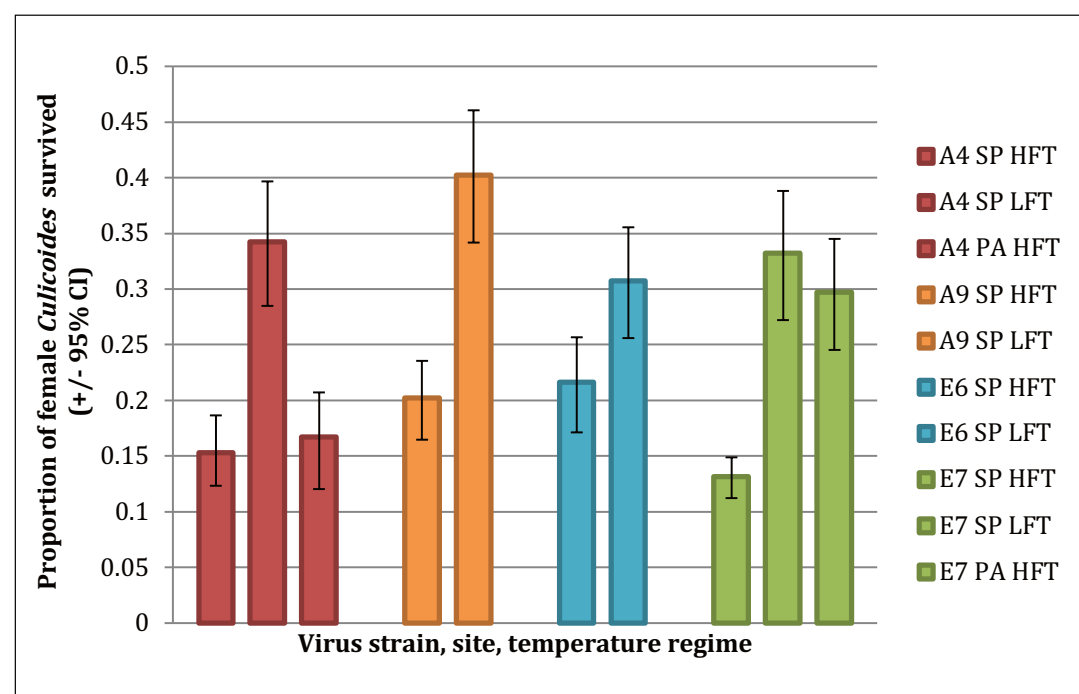

Figure 2: Proportion $( \pm 95 \% \mathrm{Cl}$ ) of Culicoides that survived the 8-day incubation period after exposure to blood spiked with AHSV-4 (A4), AHSV-9 (A9), EHDV-6 (E6) or EHDV-7 (E7), according to collection site (SP, Swiss Plateau at 650 meters above sea level [masl]; PA, pre-alpine site at 2130 masl) and temperature regime (HFT, high fluctuating temperature regime, $22 \pm 6{ }^{\circ} \mathrm{C}$; LFT, low fluctuating temperature regime, $26 \pm 6^{\circ} \mathrm{C}$ ).
Vector competence of Culicoides biting midges from Switzerland for African horse sickness virus and epizootic haemorrhagic disease virus

L.M. Maurer et al. 
Vector competence of Culicoides biting midges from Switzerland for African horse sickness virus and epizootic haemorrhagic disease virus

L.M. Maurer et al. population tested positive for the virus, this was not significantly different from the proportion testing positive from the insects from the Swiss plateau. In summary, no firm evidence of susceptibility to AHSV or EHDV infection was found for the Culicoides from the high-altitude site. This is in line with earlier finding on their susceptibility for three BTV strains. ${ }^{24}$

To date, only one comparable European study has been published. Biting midges collected in the field in Italy were fed on cotton soaked with EHDV-6-spiked blood. ${ }^{13}$ After the incubation period of constant $25^{\circ} \mathrm{C}$ for $10 \mathrm{~d}$, whole insects were processed and analysed by RT-qPCR, revealing $6 / 962(0,6 \%)$ positive midges, identified as C. obsoletus or C. scoticus. The results are difficult to compare, as feeding method, incubation temperature, incubation time and analyses of insects differed. In particular, the feeding method could have reduced infection rates due to the smaller blood meal intake. ${ }^{32}$ The shorter incubation time of eight days used in our study is in line with previous work on Culicoides vector competence. ${ }^{4,5} \mathrm{~A}$ study investigating BTV-1 infection in $C$. sonorensis revealed the peak of disseminated infections at $25^{\circ} \mathrm{C}$ at days 7 and 10 post-infection. ${ }^{36}$

A number of vector competence studies with field-collected Culicoides on AHSV and EHDV were previously carried out in South Africa. ${ }^{26,31,33-35}$ These studies examined an extensive range of different isolates of all strains of both AHSV and EHDV, including field and vaccine strains. Virus was recovered after incubation for $10 \mathrm{~d}$ at $23,5^{\circ} \mathrm{C}$, mainly from $C$. imicola and C. bolitinos, but also in lower numbers from species of other subgenera. However, whole Culicoides were processed and analysed in these studies, thus it was not possible to distinguish a mere mid-gut infection from a full dissemination. Indeed, infection rates were very variable, often below $10 \%$, but in some cases up to almost $50 \%$, due to intrinsic and extrinsic factors such as vector species and the large variability of viral load in the virus-spiked blood meals.

\section{Risk assessment for the introduction of AHSV and EHDV into Europe}

Our work suggests that Culicoides from the Swiss Plateau can act as vectors of AHSV and EHDV under summer conditions. Possible entry pathways of these viruses into Europe are infected host animals or infectious vectors. The latter is possible through wind dispersal of Culicoides vectors, which can be transported over distances of hundreds of kilometres. Indeed, wind dispersal was shown to be the driver of the range expansion of the African C. imicola to mainland France, ${ }^{15}$ and it was the incriminated method of BTV introduction from mainland Europe to the UK. ${ }^{2}$ The risk of EHDV introduction from neighbouring countries by wind dispersal of infectious vectors was considered high. ${ }^{1}$
The risk of introducing EHDV into the EU by legitimately importing infectious animals was considered negligible. However, the introduction of an infected animal through the illegal movement of livestock or transit of wild animals was considered a possibility. ${ }^{1}$

Competition horses are unlikely to aid the spread of AHSV, due to the strict regulations, but illegal equid movement are of concern, ${ }^{27}$ although the likelihood is low. Furthermore, the possibility of infection while in transit through an AHSV-infected country cannot be excluded. ${ }^{27}$ Qualitative risk assessment analyses that accounted for multiple pathways of introduction of AHSV have been conducted for France, the Netherlands and the UK. 10,12,28 They suggested the entry of an infectious host as the most likely pathway of virus introduction, although considered the risk altogether low with large spatiotemporal differences.

\section{Feeding and survival rates}

Artificial blood-feeding with a device, initially designed by Venter and colleagues ${ }^{30}$ and slightly modified in our lab, ${ }^{24}$ was efficient (feeding rates between 16-40\%). Earlier work had shown that feeding rates decreased with increasing ratios of virus cell culture supernatant to blood, ${ }^{24}$ putatively because of changed viscosity (Veronesi, unpublished). However, this was not observed in our study. Feeding rates varied between experiments, possibly because individuals of these field-collected populations were of different age and physiological status.

Survival rates after blood-feeding were dependent on altitude, temperature and - to a certain extent - virus strain. The effect of altitude could be explained through the species composition, as the pre-alpine site consisted mainly of C.grisescens, which are larger and may be more robust than the smaller $C$. obsoletus and C. scoticus collected at lower altitudes. Midges incubated at the low fluctuating temperature had significantly higher survival rates than midges incubated at the high fluctuating temperature regime. This corresponds to previous studies in which C. sonorensis infected with BTV, AHSV and EHDV and incubated under different constant temperatures had reduced survival at higher temperatures. ${ }^{21,38}$ The effect of virus strain on survival may be linked to the interaction between arboviruses and their insect hosts, and this has been shown before with Culicoides exposed to different BTV, AHSV and EHDV strains. ${ }^{24,26,31}$ However, the involved mechanisms are not investigated in Culicoides.

\section{Insect identification by MALDI-TOF MS}

Culicoides specimens were identified by subjecting homogenized thoraces to MALDI-TOF mass spectrometry. This technique is widely used in routine diagnostic microbiological laboratories for the identification of bac- 
teria and fungi. We established a corresponding database for insects, including the abundant Culicoides species. In a large-scale study with 1,200 biting midges, ${ }^{17}$ only 13 $(1 \%)$ specimens resulted in a low-quality spectrum and could not be identified. In our study 232/1,006 (23\%) yielded a low-quality spectrum. The main difference was that only the thoraces were used in our study (as the heads were analysed for viral RNA) in contrast to the former study where heads and thoraces were analysed. Though it is assumed that the major masses contributing to the fingerprints are derived from proteins of the flight muscle located in the thorax, the additional manipulation of the specimens by cutting off the head might have damaged some samples besides slightly different storage conditions (all in 70\% EtOH but for different times at different cooling temperatures). Thus, further standardization of the method is required to make full use of this simple and cost-efficient method.

\section{Acknowledgements}

The authors would like to thank Andrea Vögtlin (Institute of Virology and Immunology, Mittelhäusern, Switzerland) for supplying all virus strains and oligonucleotide sequences, Jeannine Hauri and Jasmin Varga (Institute of Parasitology, University of Zürich, Switzerland) for valuable contributions to laboratory work, Claudio Luzi and family (Juf, Switzerland) for allowing us to set the traps at their premises and for their kind support. We highly acknowledge the financial contributions of the Federal Food Safety and Veterinary Office (grant nr. 1,19,04; and sponsor of the National Centre for Vector Entomology). This publication represents the doctoral thesis of Lena Maurer, veterinarian. The publication is dedicated to Prof. Dr. med. vet. Peter Deplazes, the highly esteemed Director of the Institute of Parasitology, University of Zürich, on the occasion of his retirement and emeritation.

\section{Compétence vectorielle des mouche- rons culicoïdes de Suisse en ce qui concerne le virus de la peste équine et le virus de la maladie hémorra- gique épizootique}

Les moucherons culicoïdes sont apparus de manière inattendue en Europe en tant que vecteurs très efficaces du virus de la fièvre catarrhale du mouton lors des épidémies qui ont commencé aux Pays-Bas en 2006. Ils sont des vecteurs connus d'autres orbivirus, tels que la peste équine (AHSV) et la maladie à virus hémorragique épizootique (EHDV), qui ne sont pas endémiques en Europe. Nous avons cherché à savoir si les culicoïdes présents en Suisse à deux altitudes (Plateau suisse, 650 mètres au-dessus du niveau de la mer et Préalpes, 2130 mètres au-dessus du niveau de la mer) peuvent agir comme vecteurs pour l'AHSV et l'EHDV (deux souches chacune).

Des moucherons piqueurs ont été collectés dans des élevages, laissés se nourrir de repas de sang contaminé par le virus à travers une membrane artificielle en laboratoire et incubés pendant huit jours sous deux régimes de température $\left(22 \pm 6^{\circ} \mathrm{C}\right.$ ou $\left.26 \pm 6^{\circ} \mathrm{C}\right)$ reflétant une journée d'été ou une vague de chaleur sur le plateau suisse. La compétence vectorielle a été évaluée à partir d'homogénats de tête par RT-qPCR et isolement du virus. Dans l'ensemble, plus de 15000 moucherons piqueurs ont été exposés à l'un des quatre virus.

Des infections entièrement disséminées ont été identifiées pour les quatre souches virales chez 14 individus (6 C. obsoletus, 8 C. scoticus, identifiés par spectrométrie de

\section{Competenza del vettore moscerino Culicoides in Svizzera per il virus del- la peste equina africana e il virus del- la malattia emorragica epizootica}

I moscerini Culicoides sono apparsi improvvisamente in Europa come vettori altamente efficienti del virus della malattia della lingua blu nelle epidemie cominciate nel 2006 nei Paesi Bassi. Essi sono vettori ben conosciuti di altri orbivirus come il virus della peste equina (AHSV) e il virus della malattia emorragica epizootica (EHDV) che non sono endemici in Europa. Lo scopo di questo studio era di esaminare se i Culicoides presenti in Svizzera a due altitudini (Altopiano svizzero, 650 metri s.l.m. e regione delle Prealpi, 2130 metri s.l.m.) possono agire in quanto vettori per il AHSV e il EHDV (2 ceppi ciascuno).

I moscerini sono stati raccolti in fattorie, nutriti in laboratorio con pasti di sangue contaminato dal virus attraverso una membrana artificiale e incubati per otto giorni a due differenti condizioni di temperatura $(22 \pm$ $6{ }^{\circ} \mathrm{C}$ oppure $26 \pm 6{ }^{\circ} \mathrm{C}$ ) che riproducevano un giorno estivo o un periodo di grande caldo sull'Altopiano svizzero. La competenza del vettore è stata determinata dagli omogenati delle teste di moscerino con la RTqPCR e con l'isolamento del virus. In generale, più di 15000 moscerini sono stati esposti a uno qualsiasi dei quattro virus.

Sono state identificate delle infezioni completamente diffuse per tutti e quattro i ceppi virali mediante RTqPCR in 14 esemplari (6 C. obsoletus, 8 C. scoticus, identificati dalla spettrometria di massa MALDI-TOF),
Vector competence of Culicoides biting midges from Switzerland for African horse sickness virus and epizootic haemorrhagic disease virus

L.M. Maurer et al. 
Vector competence of Culicoides biting midges from Switzerland for African horse sickness virus and epizootic haemorrhagic disease virus

L.M. Maurer et al. masse MALDI-TOF), tous originaires du plateau suisse, par RT-qPCR. Le virus viable a pu être isolé à partir de 8 de ces échantillons. Les taux de diffusion allaient de 1 à $5 \%$. Aucune dissémination virale n'a été observée chez les moucherons piqueurs de haute altitude, appartenant majoritairement à l'espèce $C$. grisescens, qui n'ont été étudiées qu'au régime de haute température. Cependant, un modèle de régression logistique multivariable n’a révélé aucune différence statistique dans les taux de dissémination en fonction de l'origine des moucherons (altitude), de la souche virale ou du régime de température.

Ainsi, la transmission de l'AHDV et de l'EHDV est possible sur le plateau suisse mais peu probable dans la zone préalpine en considérant l'abondance des vecteurs. Les voies d'introduction potentielle du virus comprennent les déplacements illégaux d'animaux, mais aussi la dispersion par le vent sur de longues distances de culicoïdes infectieux.

Mots clés: bovins, cervidés, chevaux, introduction orbivirus, zone préalpine, plateau suisse

\section{Cumpetenza sco vector d'il muschin della spezia Culicoides ord dalla svizra per il virus dalla pestilenza africana da cavals e per il virus dalla malsogna epizootica hemorrhagica}

Ils muschins dalla spezia Culicoides ein semussai ell'Europa nunspitgadamein cun transmetter fetg effectiv il virus dalla malsogna lieunga blaua che ha priu si'entschatta 2006 ella Hollandia. Els transmettan era auters orbivirus ch'ein buca endemics ell'Europa, sco per exempel igl excitader della pestilenza da cavals africana (AHSV) e dalla malsogna hemorrhagica epizootica (EHDV). Nus havein examinau sche Culicoides, che secattan en svizra sin duas altezias sur mar (la Bassa 650 m.s.m. e la zona prealpina 2130 m.s.m.) vegnan en damonda sco vectors per AHSV e EHDV (mintgamai duas famiglias da virus).

Ils muschins ein vegni rimnai sin beins purils, ein vegni pervesi tras ina membrana artifiziala cun saun contaminaus cun virus ed ein vegni incubai otg dis sin dus scalems da temperatura $\left(22 \pm 6{ }^{\circ} \mathrm{C}\right.$ ni $\left.26 \pm 6{ }^{\circ} \mathrm{C}\right)$, che reflecteschan in di da stad ni ina perioda da calira ella Bassa. La competenza sco vector ei vegnida erruida entras RT-qPCR ed isolar il virus ord tgaus muschins homogenisai. En tut ein varga 15.000 muschins vegni confruntai cun in dils quater virus. tutti provenienti dall'Altopiano svizzero. Si sono isolati virus vitali da 8 di questi insetti. I tassi di diffusione si situavano tra $1-5 \%$. Nessuna infezione virale è stata osservata nei moscerini ad alta quota, che appartengono prevalentemente alla specie $C$. grisescens, e che sono stati studiati solo in condizioni di alta temperatura. Tuttavia, il modello di regressione logistica multivariabile non ha rilevato nessuna differenza statistica dei tassi di diffusione sulla base dell'origine dei moscerini (altitudine), ceppo del virus o condizioni di temperatura.

Quindi la trasmissione del AHDV e del EHDV è possibile nell'Altipiano svizzero ma improbabile nella regione delle Prealpi a causa della frequenza dei vettori. Le vie per un'introduzione potenziale del virus includono i movimenti illegali di animali e la dispersione eolica su grandi distanze dei Culicoides infetti.

Parole chiave: bovini, cervidi, cavalli, introduzione degli orbivirus, regione delle Prealpi, Altopiano svizzero

Tier 14 individuums (6 C. obsoletus, 8 C. scoticus, identificai entras MALDI-TOF-spectrometria), ch'ein vegni rimnai tuts ella Bassa, ei vegniu constatau entras RTqPCR infecziuns dil tuttafatg disseminadas per tuttas quater famiglias da virus. Virus vitals ein vegni isolai orda 8 da quels insecs. La quota da disseminaziun tunscheva da $1-5 \%$. Tier ils muschins da la zona pli aulta, che appartegnan prinzipalmen tier la sort C.grisescens e ch'ein vegni intercuretgs mo cul scalem ault da temperatura, han ins aflau negina infecziun da virus. In modell da regressiun logistic multivariabel ha mussau negina differenza satistica ella quota d'infektiun en correlaziun cun la derivonza d'ils muschins (aultezia sur mar), cun la famiglia dil virus ni cul scalem da temperatura.

Aschia ei ina transmissiun da AHSV ed EHDV pusseivla ella Bassa, denton strusch probabla ella zona prealpina sch'ins risguarda la frequenza d'ils vectors. Puseivladads d'importar ils virus ein dislocaziuns d'animals illegalas, mo era la derasaziun da Culicoides infeczius sur liungas distanzas cul vent.

Plaids-clav: Biestga, tscharvas, cavals, introducziun digl orbivirus, zona prealpina, Bassa 


\section{Literaturnachweis}

${ }_{1}^{1}$ Anonymous: Scientific opinion on epizootic hemorrhagic disease. EFSA Panel on Animal Health 2009: 7: 1418.

2 Burgin LE, Gloster J, Sanders C, Mellor PS, Gubbins S, Carpenter S. Investigating incursions of bluetongue virus using a model of long-distance Culicoides biting midge dispersal. Transbound. Emerg. Dis. 2013: 60: 263-272.

3 Burrage TG, Laegreid WW: African horse sickness: pathogenesis and immunity. Comp. Immunol. Microbiol. Infect. Dis. 1994: 17: 275-285.

${ }^{4}$ Carpenter S, Lunt HL, Arav D, Venter GJ, Mellor PS: Oral susceptibility to bluetongue virus of Culicoides (Diptera: Ceratopogonidae) from the United Kingdom. J. Med. Entomol. 2006: 43: 73-78.

${ }^{5}$ Carpenter S, McArthur C, Selby R, Ward R, Nolan DV, Luntz AJ, Dallas JF, Tripet F, Mellor PS: Experimental infection studies of UK Culicoides species midges with bluetongue virus serotypes 8 and 9. Vet. Rec. 2008: 163: 589-592.

${ }^{6}$ Carpenter S, Wilson A, Mellor PS: Culicoides and the emergence of bluetongue virus in northern Europe. Trends Microbiol. 2009: 17: 172-178.

${ }^{7}$ Carpenter S, Wilson A, Barber J, Veronesi E, Mellor P, Venter G, Gubbins S: Temperature dependence of the extrinsic incubation period of orbiviruses in Culicoides biting midges. PLoS ONE 2011: 6: e27987.

${ }^{8}$ Carpenter S, Veronesi E, Mullens B, Venter G: Vector competence of Culicoides for arboviruses: three major periods of research, their influence on current studies and future directions. Rev. Sci. Tech. 2015: 34: 97-112.

${ }^{9}$ Carpenter S, Mellor PS, Fall AG, Garros C, Venter GJ: African horse sickness virus: history, transmission, and current status. Annu. Rev. Entomol. 2017: 62: 343-358.

10 de Vos CJ, Hoek CA, Nodelijk G: Risk of introducing African horse sickness virus into the Netherlands by international equine movements. Prev. Vet. Med. 2012: 106: 108-122.

11 Eschbaumer M, Wernike K, Batten CA, Savini G, Edwards L, Di Gennaro A, Teodori L, Oura CA, Beer M, Hoffmann B: Epizootic hemorrhagic disease virus serotype 7 in European cattle and sheep: diagnostic considerations and effect of previous BTV exposure. Vet. Microbiol. 2012: 159: 298306.

12 Faverjon $C$, Leblond A, Hendrikx $\mathrm{P}$, Balenghien T, de Vos CJ, Fischer EAJ, de Koeijer AA: A spatiotemporal model to assess the introduction risk of African horse sickness by import of animals and vectors in France. BMC Vet. Res. 2015: 11: 127

${ }^{13}$ Federici V, Ippoliti C, Catalani M, Di Provvido A, Santilli A, Quaglia M, Mancini G, Di Nicola F, Di Gennaro A, Leone A, Teodori L, Conte A, Savini G: Epizootic haemorrhagic disease in Italy: vector competence of indigenous Culicoides species and spatial multicriteria evaluation of vulnerability. Vet. Ital. 2016: 52: 271-279.

${ }^{14} \mathrm{Fu} \mathrm{H}$, Leake CJ, Mertens PPC, Mellor PS: The barriers to bluetongue virus infection, dissemination and transmission in the vector, Culicoides variipennis (Diptera: Ceratopogonidae). Arch. Virol. 1999: 144: 747-761.
15 Jacquet S, Huber K, Pagès N, Talavera S, Burgin LE, Carpenter S, Sanders C, Dicko AH, Djerbal M, Goffredo M, Lhor Y, Lucientes J, Miranda-Chueca MA, Pereira Da Fon seca I, Ramilo DW, Setier-Rio M-L, Bouyer J, Chevillon C, Balenghien T, Guis H, Garros C: Range expansion of the bluetongue vector, Culicoides imicola, in continental France likely due to rare wind-transport events. Sci. Rep. 2016: 6: 27247.

16 Jonsdottir S, Cvitas I, Svansson V, Fettelschloss-Gabriel A, Torsteinsdottir S, Marti E: New strategies for prevention and treatment of insect bite hypersensitivity in horses. Curr. Dermatol. Rep. 2019: 8: 303-312.

17 Kaufmann C, Steinmann IC, Hegglin D, Schaffner F, Mathis A: Spatio-temporal occurrence of Culicoides biting midges in the climatic regions of Switzerland, along with large scale species identification by MALDI-TOF mass spectrometry. Parasite Vectors 2012: 5: 246.

${ }^{18}$ Kaufmann C, Mathis A, Vorburger C: Sugar-feeding behaviour and longevity of European Culicoides biting midges. Med. Vet. Entomol. 2015: 29: 17-25.

19 McLaughlin BE, DeMaula CD, Wilson WC, Boyce WM MacLachlan NJ: Replication of bluetongue virus and epizootic hemorrhagic disease virus in pulmonary artery endothelial cells obtained from cattle, sheep, and deer. Am J. Vet. Res. 2003: 64: 860-865.

20 Mellor PS, Boned J, Hamblin C, Graham S: Isolations of African horse sickness virus from vector insects made during the 1988 epizootic in Spain. Epidemiol. Infect. 1990: 105: 447-454.

${ }^{21}$ Mellor PS, Rawlings P, Baylis M, Wellby MP: Effect of temperature on African horse sickness virus infection in Culicoides. Arch. Virol. Suppl. 1998: 14: 155-163.

22 Mullens BA, Tabachnick WJ, Holbrook FR, Thompson LH: Effects of temperature on virogenesis of bluetongue virus serotype 11 in Culicoides variipennis sonorensis. Med. Vet. Entomol. 1995: 9: 71-76.

23 Paslaru Al, Torgerson PR, Veronesi E: Summer seasonal prevalence of Culicoides species from pre-alpine areas in Switzerland. Med. Vet. Entomol. 2020: 35: 324-332.

${ }_{24}$ Paslaru AP, Mathis A, Torgerson P, Veronesi E: Vector competence of pre-alpine Culicoides (Diptera: Ceratopogonidae) for bluetongue virus serotypes 1, 4 and 8 . Parasite Vectors 2018: 11: 466.

${ }_{25}$ Paweska JT, Venter GJ, Mellor PS: Vector competence of South African Culicoides species for bluetongue virus serotype 1 (BTV-1) with special reference to the effect of temperature on the rate of virus replication in $C$. imicola and C. bolitinos. Med. Vet. Entomol. 2002: 16: 10-21.

26 Paweska JT, Venter GJ, Hamblin C: A comparison of the susceptibility of Culicoides imicola and C. bolitinos to oral infection with eight serotypes of epizootic haemorrhagic disease virus. Med. Vet. Entomol. 2005: 19: 200-207.

${ }^{27}$ Robin M, Page P, Archer D, Baylis M: African horse sickness: the potential for an outbreak in disease-free regions and current disease control and elimination techniques. Equine Vet. J. 2016: 48: 659-669.

${ }^{28}$ Sabirovic M, López, M. Patel, K., Kingston, A., Hall, S: African horse sickness: potential risk factors and the likelihood for the introduction of the disease to the United Kingdom. Defra Department for Environment, Food and Rural Affairs 2008: International Animal Health: 34 pp.

${ }^{29}$ Savini G, Afonso A, Mellor P, Aradaib I, Yadin H, Sanaa M, Wilson W, Monaco F, Domingo M: Epizootic haemorragic disease. Res. Vet. Sci. 2011: 91: 1-17.
Vector competence of Culicoides biting midges from Switzerland for African horse sickness virus and epizootic haemorrhagic disease virus

L.M. Maurer et al. 
Vector competence of Culicoides biting midges from Switzerland for African horse sickness virus and epizootic haemorrhagic disease virus

L.M. Maurer et al.
30 Venter GJ, Hill E, Pajor IT, Nevill EM: The use of a membrane feeding technique to determine the infection rate of Culicoides imicola (Diptera, Ceratopogonidae) for 2 bluetongue virus serotypes in South Africa. Onderstepoort J. Vet. Res. 1991: 58: 5-9.

31 Venter GJ, Graham SD, Hamblin C: African horse sickness epidemiology: vector competence of South African Culicoides species for virus serotypes 3,5 and 8. Med. Vet. Entomol. 2000: 14: 245-250.

32 Venter GJ, Paweska JT, Lunt H, Mellor PS, Carpenter S: An alternative method of blood-feeding Culicoides imicola and other haematophagous Culicoides species for vector competence studies. Vet. Parasitol. 2005: 131: 331-335.

${ }^{33}$ Venter GJ, Paweska JT: Virus recovery rates for wild-type and live-attenuated vaccine strains of African horse sickness virus serotype 7 in orally infected South African Culicoides species. Med. Vet. Entomol. 2007: 21: 377-383.

34 Venter GJ, Wright IM, Van Der Linde TC, Paweska JT: The oral susceptibility of South African field populations of Culicoides to African horse sickness virus. Med. Vet. Entomol. 2009: 23: 367-378.

${ }^{35}$ Venter GJ, Wright IM, Paweska JT: A comparison of the susceptibility of the biting midge Culicoides imicola to infection with recent and historical isolates of African horse sickness virus. Med. Vet. Entomol. 2010: 24: 324-328.

36 Veronesi E, Antony F, Gubbins S, Golding N, Blackwell A, Mertens PPC, Brownlie J, Darpel KE, Mellor PS, Carpenter $\mathrm{S}$ : Measurement of the infection and dissemination of bluetongue virus in Culicoides biting midges using a semi-quantitative RT-PCR assay and isolation of infectious virus. PLoS ONE 2013: 8: e70800.

37 Wernike K, Elbers A, Beer M: Schmallenberg virus infection. Rev. Sci. Tech. 2015: 34: 363-373.

38 Wittmann EJ, Mellor PS, Baylis M: Effect of temperature on the transmission of orbiviruses by the biting midge, Culicoides sonorensis. Med. Vet. Entomol. 2002: 16: 147156.

39 Zientara S, Sánchez-Vizcaíno JM: Control of bluetongue in Europe. Vet. Microbiol. 2013: 165: 33-37.

40 Zimmerli U, Herholz C, Schwermer H, Hofmann M, Griot C: African horse sickness and equine encephalosis: must Switzerland get prepared. Schweiz. Arch. Tierheilkd. 2010: 152: 165-175.

\section{Korrespondenzadresse}

Alexander Mathis

National Centre for Vector Entomology

Institute of Parasitology

University of Zürich

Winterthurerestr. 266a

$\mathrm{CH}-8057$ Zürich

Telefon: +41446358536

E-Mail: alexander.mathis@uzh.ch 